๑ Entomologica Fennica. 15 June 2001

\title{
Insects inhabiting two old-growth forest polypore species
}

\author{
Atte Komonen, Juha Siitonen \& Marko Mutanen
}

Komonen, A., Siitonen, J. \& Mutanen, M. 2001: Insects inhabiting two oldgrowth forest polypore species. - Entomol. Fennica 12: 3-14.

This paper describes insect communities inhabiting two old-growth forest polypores Amylocystis lapponica and Fomitopsis rosea (Polyporaceae). Basidiocarps of both species were collected from old-growth forests in southern and eastern Finland and Russia. Samples of A. lapponica and F. rosea basidiocarps revealed insect communities of more than 50 species each, including many rare old-growth forest species. Here we report the rearing results and discuss the biology of the beetle Hallomenus sp. (Melandryidae) inhabiting A. lapponica and the beetle Cis dentatus (Cisidae), the moth Agnathosia mendicella (Tineidae) and the fly Elfia cingulata (Tachinidae) inhabiting $F$. rosea. Distribution maps of $C$. dentatus and A. mendicella in Finland are given.

Atte Komonen, Department of Ecology and Systematics, Division of Population Biology, P.O. Box 17, FIN-00014 University of Helsinki, Finland

Juha Siitonen, Finnish Forest Research Institute, P.O. Box 18, FIN-01301 Vantaa, Finland

Marko Mutanen, Virkakatu 5 C 1, FIN-90570 Oulu, Finland

Received 4 June 1999, accepted 1 December 2000

\section{Introduction}

In Finland, the area of old-growth forest has drastically declined and become increasingly fragmented. Extensive forest use in the past centuries and intensive forest management in this century have led to the transformation of virgin boreal forests in managed forests (e.g. Linder \& Östlund 1998); presently the proportion of forests older than 150 years is only about $5 \%$ of the forest land (Anon. 1996).

Old-growth boreal forests are species-rich in many taxa dependent on decaying wood (Hanski $\&$ Hammond 1995). Thousands of macrofungal species play a significant role in the forest ecosystem, as they are important decomposers of wood and other organic matter (Swift 1982). The importance of wood-decomposing fungi and es- pecially the polypores (Polyporaceae) for insects has been shown in many recent studies (e.g. Esseen et al. 1992, Kaila et al. 1994, Økland et al. 1996, Fossli \& Andersen 1998). A large proportion of beetle (Hammond \& Lawrence 1989) and fly species (McAlpine et al. 1981) are exclusively mycophagous feeding on spores, hyphae and basidiocarps. Approximately half of the recognized beetle families are at least indirectly associated with fungi and about 25 families are mycophagous in the strict sense, that is, they are dependent on fungi to complete their life-cycle (Lawrence 1989).

Fungivorous insects are faced with an exceptionally variable habitat. Habitat variability is manifested in the quality of the resource, that is in different fungal species and different stages of basidiocarp development, and in the temporal and 


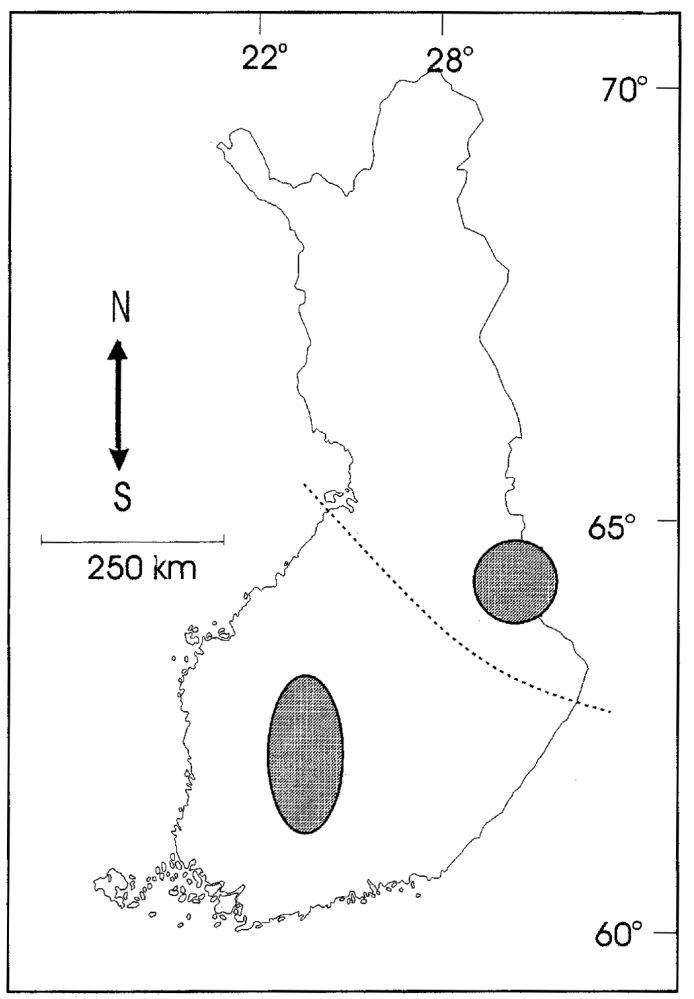

Fig. 1. The study regions in eastern Finland and Russia and in south-western Finland. The line divides Finland into two areas in terms of the occurrence of the fungal species: $3 \%$ of the known $A$. lapponica and $16 \%$ of the known $F$. rosea localities are situated in southern Finland below the line (Kotiranta \& Niemelä 1996). Each occupied $10 \times 10 \mathrm{~km}$ grid cell in the national grid system is considered one locality.

spatial occurrence of the basidiocarps (Hanski 1989). This variability constrains the insect-fungus interactions, and affects, for instance, host specificity and life-cycles of the insects. Some degree of host specificity is apparent for the many beetle, fly and moth taxa feeding on the basidiocarps of macrofungi (Hackman \& Meinander 1979, Russell-Smith 1979, Crowson 1984, Rawlins 1984). However, obligate mycophages are hardly ever monophagous, instead they inhabit a few closely related fungus species, but often have one preferred host (Paviour-Smith 1960).

The boreal forests in Finland have approx. 560 species of wood-decomposing fungi (Aphyllophorales), of which $25 \%$ are currently threatened, primarily because of the loss in the area of old- growth forest (Kotiranta \& Niemelä 1996). However, most studies on fungivorous insects have concentrated on common polypore species (Økland \& Hågvar 1994, Thunes 1994, Økland 1995, Rukke \& Midtgaard 1996, Nilsson 1997), and there is a great lack of information about the biology of the vast majority of the old-growth forest species. This study contributes to the knowledge of fungivorous insect diversity in old-growth forest polypores. The focus of the present paper is on the biology and faunistics of the specialist species inhabiting Amylocystis lapponica and Fomitopsis rosea.

\section{Material and methods}

\subsection{Fungal species}

Amylocystis lapponica (Romell) Singer and Fomitopsis rosea (Alb. \& Schwein.: Fr.) P. Karsten are wood-decomposing basidiomycetes causing brown rot. The distribution of the species is circumboreal (Ryvarden \& Gilbertson 1994), and in the boreal zone they are confined to the mesic Norway spruce (Picea abies) dominated old-growth forests. In Finland, the current distributions of A. lapponica and $F$. rosea reflect the north-eastern distribution of the remaining old-growth forests (Kotiranta \& Niemelä 1996) (Fig. 1). In suitable forests these species are among the most abundant ones, often co-occurring on trunks with Fomitopsis pinicola, Phlebia centrifuga and Phellinus ferrugineofuscus (Kotiranta \& Niemelä 1981, Renvall 1995).

In Finland, A. lapponica and F. rosea grow almost exclusively on fallen trunks of the Norway spruce, and both species prefer relatively large, hard and partly barkless trunks (Renvall 1995). Amylocystis lapponica is an annual species with new basidiocarps occurring from early August to October. The basidiocarp is usually less than $10 \mathrm{~cm}$ wide and $2 \mathrm{~cm}$ thick. Fomitopsis rosea is a perennial species in which the basidiocarps may last for many years with newly-produced hymenia every year. The basidiocarps of $F$. rosea are typically less than $7 \mathrm{~cm}$ wide and $3 \mathrm{~cm}$ thick.

\subsection{Study areas}

This study was carried out in south-western Finland (Häme) in the southern and middle boreal zone, and in eastern Finland (Kuhmo) and Russia around the middle boreal zone (Fig. 1; for the biogeographical zones, see Ahti et al. 1968). Six old-growth forests were selected from Häme and 20 old-growth forests from Kuhmo (Table 1). The proportion of old-growth forests in southern Finland is less than one percent of the forest land (E. Tomppo, unpubl. data based 
on the national forest inventory), whereas in eastern Finland the old-growth forests constitute approx. 9\% of all forests (Hiltunen et al. 1997). Most study forests have experienced only slight human impact, such as selective logging of larger trees. The overall structure of these stands has remained more or less intact, with a multilayer canopy and many decomposing logs on the ground. The study forests were mesic, mostly of the Myrtillus-type (Cajander 1949), spruce-dominated stands with paludified patches where Sphagnum spp. dominate on the forest floor. The stand characteristics, such as the area, the amount of decaying wood and the age of the dominant spruces were measured or existing data were obtained from the Finnish Forest and Park Service (Table 1).

\subsection{Collecting, rearing and identification}

388 basidiocarps of A. lapponica were collected in September 1997, and 452 basidiocarps of $F$. rosea in May 1998 (Table 1). Additionally, 66 A. lapponica basidiocarps were collected during May and June 1997 and 1998 to find out whether certain insect species overwinter inside the basidiocarps. Further, 62 F. rosea basidiocarps were collected in September 1997 to investigate the faunal succession and the life-cycle of the species. Samples were collected from several trunks in such a way that the whole area of a particular forest stand was covered. In collecting, dead or dying basidiocarps with visible marks of insect damage were preferred.

Table 1. The characteristics of the study sites and the total numbers of basidiocarps collected.

\begin{tabular}{|c|c|c|c|c|c|}
\hline \multirow[t]{2}{*}{ Locality } & \multicolumn{2}{|c|}{ Number of basidiocarps collected } & \multirow[t]{2}{*}{ Area (ha) } & \multirow{2}{*}{$\begin{array}{l}\text { Number } \\
\text { of spruce } \\
\text { logs } / \text { ha }^{2}\end{array}$} & \multirow{2}{*}{$\begin{array}{c}\text { Age of } \\
\text { dominant } \\
\text { spruces }^{3}\end{array}$} \\
\hline & F. rosea & A. lapponica & & & \\
\hline \multicolumn{6}{|l|}{ Eastern Finland } \\
\hline Kostamus (Russia) ${ }^{1}$ & 13 & 15 & 47500 & - & - \\
\hline Elimyssalo & 66 & 38 & 4500 & 42 & 196 \\
\hline Urpovaara & 40 & - & 3800 & 71 & 173 \\
\hline Tuli-Varpusuo & 32 & - & 1292 & 59 & 173 \\
\hline Issakka & 34 & 46 & 715 & $>50$ & 173 \\
\hline Louhipuro & 11 & 37 & 556 & 134 & 180 \\
\hline Peuravaara & 25 & - & 424 & 75 & 198 \\
\hline Honkavaara & 54 & 15 & 200 & 52 & 198 \\
\hline Jauhovaara & 11 & 15 & 150 & 18 & 165 \\
\hline Louhivaara & 23 & 7 & 100 & 73 & 198 \\
\hline Rajalampi & 28 & - & 82 & 104 & 186 \\
\hline Luhtavaara & 5 & - & 13.7 & 51 & 167 \\
\hline Vepsä & 9 & - & 11.6 & 23 & 136 \\
\hline Luvesuo & 1 & - & 8.5 & 60 & 167 \\
\hline Jonkeri & 21 & - & 7.6 & 133 & 196 \\
\hline Puntari & 17 & - & 7.0 & 76 & 181 \\
\hline Lauvuskylä & 13 & - & 5.8 & 112 & 171 \\
\hline Lehtopuro & 23 & 26 & 5.4 & 170 & 167 \\
\hline Iso-Matojärvi & 20 & - & 4.3 & 120 & 181 \\
\hline Kuivikkovaara & 18 & - & 3.0 & 54 & 227 \\
\hline Total & 464 & 199 & & & \\
\hline \multicolumn{6}{|l|}{ Southern Finland } \\
\hline Pyhä-Häkki & 33 & 26 & 580 & - & 175 \\
\hline Petäjäjärvi & - & 57 & 130 & 34 & 151 \\
\hline Vesijako & - & 52 & 120 & 35 & 140 \\
\hline Lehtivehmas & - & 43 & 50 & 18 & 154 \\
\hline Musturi & - & 20 & 19 & 62 & 122 \\
\hline Nuijakorpi & 17 & 57 & 2.8 & 109 & 165 \\
\hline Total & 50 & 255 & & & \\
\hline
\end{tabular}

${ }^{1} \mathrm{ca} 15 \mathrm{~km}$ east of the Finnish border at $64^{\circ} \mathrm{N}$.

2 Minimum diameter $10 \mathrm{~cm}$ at breast height.

${ }^{3}$ The average age of ten spruces belonging to the dominant canopy storey. 
To rear out the insects, the basidiocarps were placed in cloth-covered plastic boxes and kept in outdoor conditions, except the $F$. rosea basidiocarps from Häme, which were taken indoors. Rearings were checked for insects once a month and all emerged individuals were preserved in alcohol or as dry specimens; Collembola were not recorded. In late December, A. lapponica basidiocarps were transferred to a cold-room and kept at $4-6^{\circ} \mathrm{C}$. In late March, the rearings were moved to room temperature to promote the emergence of overwintering species. The larvae of most mycetophilid species require their fungus food alive, in which respect they differ from most fungivorous Diptera of other families (Buxton 1960). Because of this, the success of the rearing was assessed by carefully dissecting the A. lapponica basidiocarps in May for possible dead mycetophilids.

All adults were identified to species as far as possible. If males of Mycetophila dentata were reared together with females, all the females were considered to belong to this species (following a careful examination), but if only females were reared they were identified as Mycetophila sp., although it is probable that they all were $M$. dentata (A. Polevoi pers. comm.).

In order to exclude accidental host records, an accepted breeding record for a cisid species had to fulfill one of the following criteria: 1) ten or more fully pigmented adults, 2) two or more teneral (= young, not fully pigmented) adults, 3 ) one teneral and two or more fully pigmented adults, and 4) one or more larvae and/or pupae (Lawrence 1973). All available records of Cis dentatus in Finland were gathered from published papers, from the natural history museums of Helsinki, Turku, Jyväskylä, Oulu and Joensuu, and from the private collections of several coleopterologists. For the moth Agnathosia mendicella the corresponding data were obtained with a query addressed to the members of the Lepidopterological Society of Finland.

\section{Results and discussion}

\subsection{Taxa reared from A. lapponica}

Amylocystis lapponica harbored an insect community of 60 species: 37 coleopteran $(n=1913)$, 13 dipteran $(n=289), 8$ hymenopteran $(n=93)$ and 2 heteropteran species $(n=2)$ (Appendix 1). Most species, excluding some Diptera and Hymenoptera, emerged before the winter. The rearing procedure caused the death of all Hallomenus larvae and approx. 1000 dipteran larvae (Mycetophilidae and some unidentified families), which inevitably affected the species-abundance relationships of Diptera, but not necessarily the species composition. The most crucial point for successful rearings seems to be the time when basidiocarps are collected in relation to the de- velopmental stage of the insects: the closer the individuals are to pupation the more probable it is that they are able to complete their life-cycle in the rearing.

\subsubsection{Hallomenus $s p$.}

The melandryid beetle Hallomenus sp. was the numerically-dominant species inhabiting the basidiocarps of A. lapponica. It occurred in all the forest stands studied and the fraction of occupied basidiocarps per study site ranged from 6 to 85\% (mean 42\%). Hallomenus larvae, probably representing $H$. axillaris (J. Muona pers. comm.), accounted for close to $70 \%$ of all the individuals in the sample, but only one adult $H$. axillaris emerged from the basidiocarps. It is obvious that the rearing changed the microclimate and watercontent of the basidiocarps to such an extent that Hallomenus larvae could not complete their development. To our knowledge this is the first definite host record for this species.

Many melandryid beetle species are known to overwinter as larva and to pupate inside the basidiocarp (Palm 1951; pers. obs.). Because the A. lapponica basidiocarps are very moist, become always mouldy and have a short duration after death, it is unlikely that Hallomenus individuals could overwinter inside the basidiocarps either as larvae or pupae. Moreover, the high density of Hallomenus larvae - up to more than 80 individuals in a single small-sized basidiocarp - implies that there is practically no room for the fullgrown larvae to pupate. Therefore the species most likely completes the development and pupates in the leaf litter, although none of the approx. 50 larvae used the turf provided for pupation. This was probably due to unsuitable rearing conditions since the larvae eagerly crawled into the turf.

\subsubsection{Other species}

The other primary fungivores inhabiting $A$. lapponica were fungus gnats (Mycetophilidae) and cisid beetles (Cisidae). Many dipteran species in the genera Ula, Bolitophila and Mycetophila utilized A. lapponica. Almost all species emerged during the autumn, and adult insects were 
observed even in mid-November. However, $75 \%$ of the Ula bolitophila (Tipulidae) and some mycetophilid individuals pupated and the adults emerged in the spring. In mycetophilids, overwintering as adults is mainly restricted to the genus Exechia, so it is likely that in natural conditions most of the mycetophilid species inhabiting A. lapponica emerge in the spring. As the fruiting bodies have a poor duration over the winter, it is possible that the species complete their development and pupate in the leaf litter.

Beetles of the family Cisidae are commonly found in polyporous fungi. However, the cisids did not prefer A. lapponica as a breeding habitat, probably because the basidiocarps are relatively moist and have a short duration. The cisid adults are long-lived and they often form long-lasting communities with overlapping generations (Entwistle 1955). Eight individuals of Cis dentatus (none of them was teneral) emerged from $A$. lapponica basidiocarps (see section 3.2.2). In addition to a few occasional individuals, Cis glabratus was able to breed in one relatively dry basidiocarp of A. lapponica from which over 50 adults emerged. This suggests that the microclimatic conditions inside the basidiocarp are of importance for the successful breeding of the Cisidae.

Besides the cisids, many other beetle species belonging to various families were reared from the basidiocarps (Appendix 1). Most of these species are not dependent on polypores, but are saproxylic (e.g. Rhizophagidae: Rhizophagus dispar) and associated with many fungi growing on trees or dead wood in general (Koch 1989). However, some species are likely to be spore feeders or feed on molds growing on the surfaces of basidiocarps (e.g. Latridiidae), or prey on larvae of other species (e.g. Elateridae: Harminius undulatus larvae).

Two fungivorous Diptera new for Finland were reared from $A$. lapponica: the phorid fly Megaselia frameata $(n=9)$ and the mycetophilid fly Sciophila hebes $(n=1)$. Megaselia frameata has been reared from many fungal hosts in many parts of Europe (H. Disney pers. comm.). The species breeds in annual fungi with relatively soft basidiocarps. Sciophila hebes is a holarctic species and previously known only from the Primorye Territory and Kuril Islands in the Russian Far East
(Zaitzev 1982, 1994). This is the first record of the species from the Western Palaearctic. According to Alexei Polevoi (pers. comm.), the shape of the IX tergite differs slightly from those of Zaitzev individuals, but based on just one male it is impossible to decide whether it would present an undescribed species.

\subsection{Taxa reared from $F$. rosea}

Fomitopsis rosea hosted an insect community of 54 species: 36 coleopteran $(n=109), 4$ sciarid fly $(n=44)$, one tachinid fly $(n=115), 3$ lepidopteran $(n=239)$ and 10 hymenopteran species $(n=$ 31) (Appendix 2). The insect community included two world-wide rarities (the beetle Eucilodes caucasicus, Eucinetidae, $n=3$, and the fly Trichosia (Baeosciara) sinuata, Sciaridae, $n=34$ ) and two species "rare" in Europe (the beetle Cis dentatus, Cisidae, $n=23$, and the moth Agnathosia mendicella, Tineidae, $n=210$ ). We use the term "rare" to signify small local population size and restricted habitat requirements (Kunin \& Gaston 1997). The numerically dominant food chain consisted of $F$. rosea, the moth $A$. mendicella and the fly Elfia cingulata (Tachinidae), a parasitoid apparently specializing on A. mendicella in oldgrowth forests (Komonen et al. 2000).

\subsubsection{Agnathosia mendicella and Elfia cingulata}

Agnathosia mendicella is a scarce but widely distributed species in Europe (Zagulajev 1978). From Finland, 349 individuals of the species have been reported from 69 localities $(10$ x $10 \mathrm{~km}$ grid cells in the national grid system; Fig. 2); the share of this study out of these figures is 210 individuals and 13 localities.

Agnathosia mendicella has been reared from fungal species growing on birch (Betula sp.) and oak (Quercus robur) in Central Europe (Zagulajev 1978). In Finland, the species has been reared from F. rosea (this study) and Daedalus quercina (3 individuals). There are also some poorly documented records from white, annual fungi growing on woodstack and barn. Daedalus quercina grows on oak, which is scarce and confined mainly to the hemiboreal zone in south-westernmost Fin- 


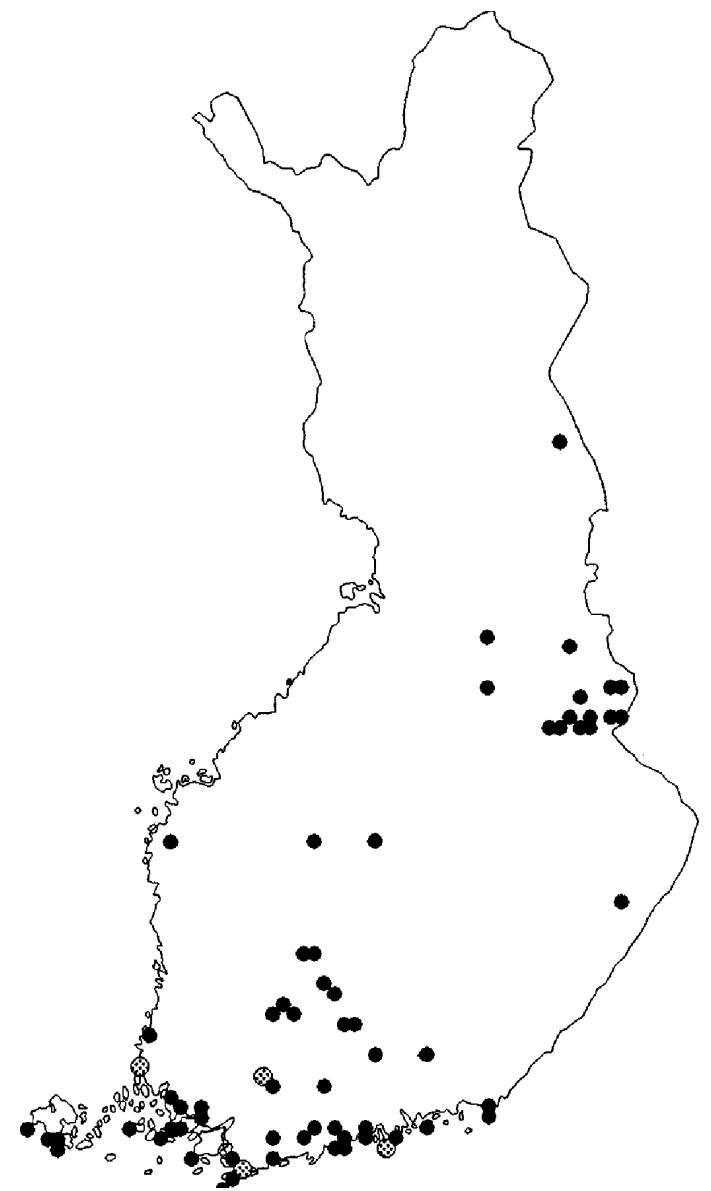

Fig. 2. The distribution of $A$. mendicella in Finland. Localities are $10 \times 10 \mathrm{~km}$ grid cells in the national grid system. Dark circles represent records after the year 1970, gray circles records before the year 1970 .

land. At least 22 of the 69 occupied grid cells are spruce-dominated old-growth forest sites. As there are only a few remnant and small populations of $F$. rosea in southern Finland, an interesting question arises: Is there a host species shift of $A$. mendicella as we move from the south to the north? The answer is unknown, but it is evident that $A$. mendicella specializes on $F$. rosea in spruce-dominated, unmanaged mature or oldgrowth forests.

In Finland, the adult flight period is 6 June to 7 September, the peak being in July (Fig. 3). The variation in the flight period is likely to reflect annual variation in weather conditions, as the flight period is not earlier in the southern Finland than

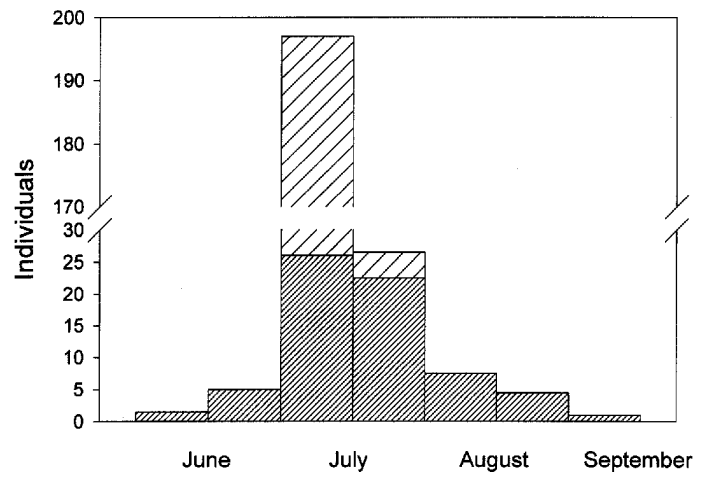

Fig. 3. The flight period of $A$. mendicella. Dark shading indicates the numbers of individuals caught by trapping or netting before this study and light shading the individuals reared in this study. The flight period is divided in two-week time intervals starting from the first of June. The month intervals are only illustrative and do not fit exactly the two-week intervals. If the trapping period of an individual overlapped two time intervals, half an individual was included in each period.

in the north. It is probable that A. mendicella has a one-year life-cycle, because in the rearings all the individuals overwintered only once (it is difficult to verify whether some individuals had already overwintered before the sampling). However, the variation in the flight period indicates that the development of an individual can show remarkable temporal variation, and in the most extreme case such variation might lead to a twoyear development.

An adult $A$. mendicella lays eggs on the basidiocarp and the young larvae crawl into the basidiocarp. The newly-hatched larvae start to construct tunnels and mobile cases by spinnig a silky web on which frass and debris are stuck. The larvae live mainly inside the tunnels and feed on the fungal tissue by touching the actual substrate only with the mouthparts. The function of the silky web is apparently a defense against parasitoids and predators (Rawlins 1984). Basidiocarps inhabited by A. mendicella (or moths in general) can be identified by the debris underneath the basidiocarp, spun together by the silk (see the photograph in Komonen \& Mutanen 1999).

The larvae overwinter inside the basidiocarp, and the full-grown larvae pupate underneath it 
mainly in June and July. The pupal period is about two weeks. Agnathosia mendicella is nocturnal in behavior and single adults have been caught at dusk with a net or with light traps. The number of individuals reared from one basidiocarp ranged from 1 to $15($ mean $=2.28)$. The sex ratio of the reared $A$. mendicella was male biased, 102 males and 64 females $\left(\chi^{2}=4.41, d f=1, p=0.036\right)$ (the sex of all individuals was not possible to determine because of damaged individuals). $63 \%$ of the 35 basidiocarps occupied by at least two individuals were inhabited by both sexes and since no large broods of a single sex was observed it is evident that sexual reproduction is typical for the species.

Agnathosia mendicella was parasitized by the tachinid fly Elfia cingulata, which is a scarce but wide-spread species in Europe (Andersen 1988). The species has been reported to parasitize microlepidopteran larvae living in decaying wood or on several species of fungi and lichens (Belshaw 1993). In general, the Tachinidae show an association with a particular host family or (more rarely) genus, although some monophagous species also exist (Eggleton \& Gaston 1992). Some species attack hosts in particular ecological situations, such as larvae living inside fungal basidiocarps. Because many host species of the genus Elfia are concealed it is likely that the genus is larviparous, that is, the first-instar larva contacts the host rather than the egg being laid on it (Belshaw 1993).

The adults of $E$. cingulata emerged from 1 July to 14 July, and the number of individuals per occupied basidiocarp ranged from 1 to 13 (mean = $3.03)$. The sex ratio of $E$. cingulata was slightly female biased: 66 females and 45 males $\left(\chi^{2}=2.00\right.$, $d f=1, p=\mathrm{ns}) .41 \%$ of the 37 basidiocarps occupied by E. cingulata included both sexes. Although most Tachinidae overwinter as puparia, it is probable that $E$. cingulata overwinters as a larva like the closely-related E. nigrina, which diapauses as a second-instar larva (Tachinidae have 3 larval instars) inside the host and pupates in the empty host pupa (Belshaw 1993). Because the adult stage lasts for 1 to 2 months and the larval and pupal stages last for 1 to 3 weeks, it is evident that in Finland E. cingulata has only one generation per year.

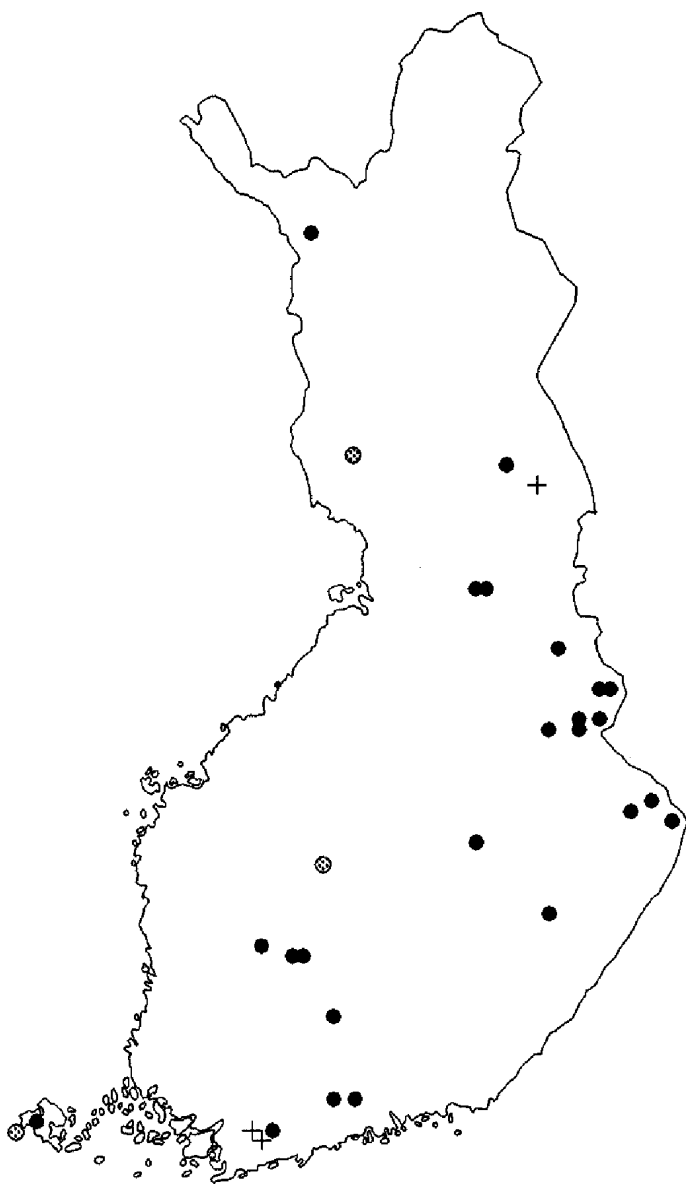

Fig. 4. The distribution of $C$. dentatus in Finland. For details see Fig. 2. Crosses represent records before 1970 without exact coordinates; the cross is located in the capital city of the county from which the specimen was obtained.

\subsubsection{Cis dentatus}

Cis dentatus is a scarce but widely distributed species in Europe (Kloet \& Hincks 1977, Koch 1989, Jelínek 1993, Silfverberg 1992, Siitonen et al. 1995), and it cannot be considered a genuine boreal species. From Finland, about 80 individuals of the species have been reported from 30 localities (Fig. 4). We reared 29 individuals of $C$. dentatus from $F$. rosea basidiocarps and 8 from A. lapponica (see section 3.1.2). In Fennoscandia, most of the $C$. dentatus records are from oldgrowth coniferous forests. 
In central Europe, the species has been found mostly in coniferous forests in mountain regions; host fungus records include Fomitopsis pinicola, Antrodia serialis, Ischnoderma benzoinum, Pycnoporellus fulgens and Piptoporus betulinus (Koch 1989; J. Reibnitz pers. comm.). In Fennoscandia, only a few scattered records have been reported from $F$. pinicola in spite of extensive rearings of this polypore (Økland \& Hågvar 1994, Jonsell 1999). We reared altogether 6 teneral individuals. Using Lawrence's (1973) criteria, the rearing record for $C$. dentatus was obtained from two $F$. rosea basidiocarps. The species has also been recorded from $F$. rosea in old-growth forests in Sweden (M. Jonsell pers. comm., pers. obs.). These observations imply that the association of $C$. dentatus with $F$. rosea in suitable habitats is more than occasional. However, $C$. dentatus larvae, pupae and teneral adults have also been found on A. serialis (B. Ehnström, P. Martikainen pers. comm., pers. obs.). Lawrence's (1973) quite conservative criteria may well underestimate the importance of $F$. rosea for $C$. dentatus, which population size rarely reaches high numbers typical for many other cisid species. Nevertheless, the importance of $A$. serialis and other resupinate brown-rotting polypores as primary hosts for $C$. dentatus deserve further study.

\subsubsection{Other species}

A sciarid fly species, Trichosia (Baeosciara) sinuata, new for Finland was reared from $F$. rosea. The species is known by the holotype from Austria (Menzel \& Mohrig 1997) but as the species' current taxonomic status is problematic it is redescribed by P. Vilkamaa and A. Komonen (manuscript). Trichosia sinuata has probably specialized on living in polypores because the females have a long ovipositor similar to that in species, which are known to lay eggs in the basidiocarps of polyporous fungi. The coleopteran Eucilodes caucasicus is only known from a few localities in Finland and from the Caucasus between the Black and Caspian Sea (Rassi et al. 1986). Previously it has been recorded from fallen Norway spruce decayed by Trichaptum abietinum (Kangas 1953). We found three individuals inside one basidiocarp of $F$. rosea that had been heavily eaten by other species.

\section{Conclusions}

Old-growth boreal forests are surprisingly species-rich in taxa associated with the decomposition of dead trees, and many species have highly specialized microhabitat requirements. Our study revealed that many specialist insect species inhabit polypores dependent on old-growth forest. Forest management, especially the removal of dead and weakened trees in thinning operations, clear-cut regeneration, subsequent soil preparation in which decaying logs are destroyed, and short rotation times all have a negative impact on the populations of old-growth forest species. Of the species reared at the present study, Hallomenus, A. mendicella and $C$. dentatus are prime examples of rare species that have a wide geographical distribution but restricted habitat requirements and relatively small local population sizes. This makes the species vulnerable to local extinction resulting from forestry-related habitat destruction.

Despite the common co-occurrence of $F$. rosea and $A$. lapponica on the spruce trunks, both species harbored a distinct insect community. This is most likely a consequence of the different life histories of these polypore species. Amylocystis lapponica, an annual species, is inhabited by fungus gnats and beetles with short development time, whereas $F$. rosea, a perennial species, is favored by species such as $A$. mendicella, which have a relatively long development time. Further, of the species inhabiting $F$. rosea, only very few are known to breed in $F$. pinicola, which is a common species in managed forests. This shows that even taxonomically and ecologically related polypore species can host a completely different fauna.

Acknowledgements. Our thanks are due to specialists who identified particular taxa: Dr. R. Henry L. Disney (Phoridae), Dr. Jyrki Muona (Hallomenus larvae), Dr. Alexei Polevoi (Mycetophilidae and Tipulidae), Dr. HansPeter Tschorsnig (Tachinidae), Dr. Reijo Jussila, Mr. Gergely Várkonyi, Mr. Veli Vikberg (Hymenoptera), and Dr. Pekka Vilkamaa (Sciaridae). We would also like to thank the Research Centre of the Friendship Park, the Finnish Forest and Park Service and the Lammi Biological Station, which provided us the facilities to complete this study. This study is part of the Finnish Biodiversity Research Program (FIBRE) and was supported by the research grant to the project Biodiversity in Boreal Forests. 


\section{References}

Ahti, T., Hämet-Ahti, L. \& Jalas, J. 1968: Vegetation zones and their sections in northwestern Europe. - Ann. Bot. Fennici 5: 169-211.

Andersen, S. 1988: Revision of European species of Phytomyptera Rondani (Diptera: Tachinidae). Entomol. Scand. 19: 43-80.

Anonymous 1996: Statistical Yearbook of Forestry. — The Finnish Forest Research Institute, Helsinki, Finland.

Belshaw, R. 1993: Tachinid flies (Diptera: Tachinidae). Handbk Ident. Br. Insects 10: 1-169.

Buxton, P. A. 1960: British Diptera associated with fungi. III. Flies of all families reared from about 150 species of fungi. - Entomol. Mon. Mag. XCVI: 61-94.

Cajander, A. K. 1949: Forest types and their significance. - Acta Forestalia Fennica 56: 1-71.

Crowson, R. A. 1984: The associations of Coleoptera with Ascomycetes. - In: Wheeler, Q. \& Blackwell, M. (eds), Fungus-Insect Relationships: 256-285. Columbia Univ. Press, New York. 514 pp.

Eggleton, P. \& Gaston, K. J. 1992: Tachinid host ranges: a reappraisal (Diptera: Tachinidae). — Entomologist's Gazette 43: 139-143.

Entwistle, H. M. 1955: The biology and morphology of the fungus beetles of the family Cisidae and their parasites. - Unpubl. thesis. Huxley Library, Imperial College, London. $150 \mathrm{pp}$.

Esseen, P. A., Ehnström, B., Ericson, L. \& Sjöberg, K. 1992: Boreal forests - the focal habitats of Fennoscandia. In: Hansson, L. (ed.), Ecological Principles of Nature Conservation: 252-325. Elsevier, London. 436 pp.

Fossli, T.-E. \& Andersen, J. 1998: Host preference of Cisidae (Coleoptera) on tree-inhabiting fungi in northern Norway. - Entomol. Fennica 9: 65-78.

Hackman, W. \& Meinander, M. 1979: Diptera feeding as larvae on macrofungi in Finland. - Ann. Zool. Fennici 16: $50-83$.

Hammond, P. M. \& Lawrence, J. F. 1989: Mycophagy in insects: A summary. - In: Wilding, N., Collins, N. M., Hammond, P. M. \& Webber, J. F. (eds), Insect-fungus interactions: 275-324. Academic Press. $344 \mathrm{pp}$.

Hanski, I. 1989: Fungivory: fungi, insects and ecology. In: Wilding, N., Collins, N. M., Hammond, P. M. \& Webber, J. F. (eds), Insect-Fungus Interactions: 25-68. Academic Press. 344 pp.

Hanski, I. \& Hammond, P. 1995: Biodiversity in boreal forests. - TREE 10: 5 .

Hiltunen, V., Kytövuori, T., Siira, J., Jorri, E.-L., Leskinen, A., Leskinen, J., Meriruoko, A., Santala, E., Tolonen, A. \& Tolonen, J. 1997: Kainuun alueen luonnonvarasuunnitelma. - Metsähallituksen metsätalouden julkaisuja 8. Vantaa, Finland. 76 pp.

Jelínek, J. 1993: Check-list of Czechoslovak Insects IV (Coleoptera). - Folia Heyrovskyana. Suppl. 1. Praha.

Jonsell, M. 1999: Insects on Wood-Decaying Polypores: Conservation Aspects. - Doctoral thesis. Swedish
University of Agricultural Sciences, Uppsala.

Kaila, L., Martikainen, P., Punttila, P. \& Jakovlev, E. 1994: Saproxylic beetles on dead birch trunks: effect of polypore species decaying the trunk. - Ann. Zool. Fennici 31: 97-107.

Kangas, Y. 1953: Drei bemerkenswerte Käferfunde aus Mittelfinland. - Ann. Entomol. Fennici 19: 124-129.

Kloet, G. S. \& Hincks, W. D. 1977: A check list of British Insects. - Handbk Ident. Br. Insects. 11: 1-105.

Koch, K. 1989: Die Käfer Mitteleuropas. Ökologie. — Goecke \& Evers Verlag, Krefeld, Germany. 440 pp.

Komonen, A. \& Mutanen, M. 1999: Agnathosia mendicellan (Tineidae) biologia ja levinneisyys Suomessa. Baptria 24(4): 201-207.

Komonen, A., Penttilä, R., Lindgren, M. \& Hanski, I. 2000: Forest fragmentation truncates a food chain based on an old-growth forest bracket fungus. — Oikos 90: 119126.

Kotiranta, H. \& Niemelä, T. 1981: Composition of the polypore communities of four forest areas in southern Central Finland. - Karstenia 21: 31-48.

Kotiranta, H. \& Niemelä, T. 1996: Threatened Polypores in Finland. — Finnish Environment Institute. Edita, Helsinki, Finland. 184 pp.

Kunin, W. E. \& Gaston, K. J. 1997: The biology of rarity: Causes and consequences of rare-common differences. Chapman \& Hall.

Lawrence, J. F. 1973: Host preference in Ciid beetles (Coleoptera: Ciidae) inhabiting the fruiting bodies of basidiomycetes in North America. - Bull. Mus. Comp. Zool 145: 163-212.

Lawrence, J. F. 1989: Mycophagy in the Coleoptera: Feeding strategies and morphological adaptions. - In: Wilding, N., Collins, N. M., Hammond, P. M. \& Webber, J. F. (eds), Insect-fungus interactions: 1-23. Academic Press. 344 pp.

Linder, P. \& Östlund, L. 1998: Structural changes in three mid-boreal Swedish forest landscapes, 1885-1996. Biol. Cons. 85: 9-19.

McAlpine, J. F., Peterson, B. V., Shewell, G. E., Teskey, H. J., Vockeroth, J. R. \& Wood, D. M. 1981: Manual of Nearctic Diptera. Vol 1. — Biosystematics Research Institute Ottawa, Ontario. Research Branch Agriculture Canada. Monograph No. 27. 674 pp.

Menzel, F. \& Mohrig, W. 1997: Revision der paläarktischen Arten von Trichosia WINNERTZ sensu Tuomikoski, 1960 (Diptera, Sciaridae). Teil I. Gattung Trichosia WINNERTZ, 1867. - Studia Dipterologica 4: 3-40.

Nilsson, T. 1997: Spatial population dynamics of the Black tinder fungus beetle, Bolitophagus reticulatus. - Dr. Scient. Thesis, Department of Zoology, University of Uppsala, Sweden.

Økland, B. 1995: Insect fauna compared between six polypore species in a southern Norwegian spruce forest. - Fauna Norv. Ser. B 42: 21-26.

Økland, B. \& Hågvar, S. 1994: The insect fauna associated with carpophores of the fungus Fomitopsis pinicola (Fr.) Karst. in a southern Norwegian spruce forest. — Fauna 
Norv. Ser. B 41: 29-42.

Økland, B., Bakke, A., Hågvar, S. \& Kvamme, T. 1996: What factors influence the diversity of saproxylic beetles? A multiscaled study from a spruce forest in southern Norway. — Biod. and Cons. 5: 75-100.

Palm, T. 1951: Die Holz- und Rinden-Käfer der nordschwedischen Laubbäume. - Meddelanden från statens skogsforskningsinstitut $40.242 \mathrm{pp}$.

Paviour-Smith, K. 1960: The fruiting-bodies of macrofungi as habitats for beetles of the family Ciidae (Coleoptera). - Oikos 11: 43-71.

Rassi, P., Alanen, A., Kemppainen, E., Vickholm, M. \& Väisänen, R. 1986: Uhanalaisten eläinten ja kasvien suojelutoimikunnan mietintö II. Suomen uhanalaiset eläimet. Komiteanmietintö 43/1985. Ympäristöministeriö, Helsinki. 466 pp.

Rawlins, J. E. 1984: Mycophagy in Lepidoptera. - In: Wheeler, Q. \& Blackwell, M. (eds), Fungus-Insect Relationships: 382-423. Columbia University Press, New York. 514 pp.

Renvall, P. 1995: Community structure and dynamics of wood-rotting Basidiomycetes on decomposing conifer trunks in northern Finland. - Karstenia 35: 1-51.

Rukke, B. \& Midtgaard, F. 1996: The importance of scale and spatial variables for the fungivorous beetle Bolitophagus reticulatus (L.) (Coleoptera, Tenebrionidae) in a fragmented forest landscape. Ecography 21: 561-572.

Russell-Smith, A. 1979: A study of fungus flies (Diptera: Mycetophilidae) in beech woodland. - Ecol. Entomol.
4: $355-364$.

Ryvarden, L. \& Gilbertson, R. L. 1994: European Polypores 1. Abortiporus-Lindtneria. - Synopsis Fungorum 6. $387 \mathrm{pp}$.

Siitonen, J., Martikainen, P., Kaila, L., Nikula, A. \& Punttila, P. 1995: Kovakuoriaislajiston monimuotoisuus eri tavoin käsitellyillä metsäalueilla Suomessa ja Karjalan tasavallassa. - Metsäntutkimuslaitoksen tiedonantoja 564: 43-63.

Silfverberg, H. 1992: Enumeratio Coleopterorum Fennoscandiae, Daniae et Baltiae. - Helsingin Hyönteisvaihtoyhdistys. Helsinki, Finland.

Swift, M. J. 1982: Basidiomycetes as components of forest ecosystems. - In: Frankland, J. C., Hedger, J. N. \& Swift, M. J. (eds), Decomposer Basidiomycetes: their biology and ecology: 307-337. Cambridge University Press, Cambridge. 355 pp.

Thunes, K. H. 1994: The coleopteran fauna of Piptoporus betulinus and Fomes fomentarius (Aphyllophorales: Polyporaceae) in western Norway. - Entomol. Fennica 5: $157-168$.

Zagulajev, A. K. 1978: Tineidae. Part 2. Fauna of the U.S.S.R. Lepidoptera Vol. IV. No. 2. - Israel Program for Scientific Translations, Jerusalem. 436 pp.

Zaitzev, A. I. 1982: Fungus gnats of the genus Sciophila Meig. (Diptera: Mycetophilidae) in Holarctic region. Nauka, Moscow. 75 pp. (In Russian)

Zaitzev, A. I. 1994: Fungus gnats of the fauna of Russia and adjacent regions. Part 1. — Nauka, Moscow. 288 pp. (In Russian.) 
Appendix 1. Taxa reared from Amylocystis lapponica.

\begin{tabular}{|c|c|c|c|}
\hline \multirow{2}{*}{$\frac{\text { Species }}{\text { Heteroptera }}$} & \multirow[t]{2}{*}{ Individuals } & \multirow{2}{*}{$\begin{array}{l}\text { Species } \\
\text { Staphylinidae }\end{array}$} & ndividuals \\
\hline & & & \\
\hline Aradidae & & Quedius plagiatus (Mannerheim) & 1 \\
\hline Aradus betulinus Fn. & 1 & Nudobius lentus (Gravenhorst) & 1 \\
\hline Aradus ? corticalis (L.) & 1 & Acrulia inflata (Gyllenhal) & 13 \\
\hline TOTAL & 2 & Hapalaraea linearis (Zetterstedt) & 43 \\
\hline Diptera & & Phloeonomus lapponicus (Zetterstedt) & 4 \\
\hline Tipulidae & & Ischnoglossa elegantula (Mannerheim) & 1 \\
\hline Discobola caesarea (Osten Sacken) & 1 & Liogluta microptera Thomson & 1 \\
\hline Ula bolitophila Loew & 58 & Atheta (Sg. Microdota) subtilis (Scriba) & 4 \\
\hline Ula sylvatica (Meigen) & 1 & Atheta (Sg. Xenota) myrmecobia (Kraatz) & 1 \\
\hline Chironomidae & 3 & Atheta (Sg. Alaobia) pallidicornis (Thomson) & 1 \\
\hline Mycetophilidae & & Atheta (Sg. Atheta) pilicornis (Thomson) & 2 \\
\hline Bolitophila occlusa Edwards & 66 & Bolitochara mulsanti Sharp & 2 \\
\hline Sciophila hebes Johansen & 1 & Leptusa pulchella (Mannerheim) & 10 \\
\hline Mycetophila dentata Lundström & 102 & Elateridae & \\
\hline Mycetophila marginata Winnertz & 3 & Harminius undulatus (Degeer) (larvae) & 18 \\
\hline Mycetophila sp. & 19 & Trogossitidae & \\
\hline Sciaridae & 15 & $\begin{array}{l}\text { Ostoma ferruginea (Linnae } \\
\text { Nitidulidae }\end{array}$ & 21 \\
\hline Scatopsciara sp. & 6 & Epuraea boreella (Zetterstedt) & 1 \\
\hline Cecidomyiidae & 3 & Epuraea variegata (Herbst) & 14 \\
\hline Clusiidae & 1 & Rhizophagidae & \\
\hline Phoridae & & Rhizophagus dispar (Paykull) & 96 \\
\hline Megaselia frameata Schmitz & 9 & Cucujidae & \\
\hline Sphaeroceridae & 1 & Dendrophagus crenatus (Paykull) & 1 \\
\hline TOTAL & 289 & Cryptophagidae & \\
\hline Hymenoptera & & Cryptophagus dorsalis Sahlberg & 1 \\
\hline Pteromalidae & & Atomaria pulchra Erichson & 1 \\
\hline Pegopus inornatus (Walker) & 1 & Corylophidae & \\
\hline Diapriidae & & Orthoperus punctatus Wankowicz & 26 \\
\hline Belytinae & & Latridiidae & \\
\hline Cinetus piceus Thomson & 58 & Latridius consimilis Mannerheim & 1 \\
\hline Miota sp. & 4 & Latridius minutus (Linnaeus) & 1 \\
\hline Braconidae & & Corticaria rubripes Mannerheim & 2 \\
\hline Doryctinae & & Cortinicara gibbosa (Herbst) & 1 \\
\hline Ontsira antica (Wollaston) & 22 & Cisidae & \\
\hline Ontsira sp. & 1 & Cis glabratus Mellié & 62 \\
\hline Ichneumonidae & & Cis jacquemartii Mellié & 1 \\
\hline Orthocentrinae & & Cis lineatocribratus Mellié & 1 \\
\hline Proclitus sp. & 4 & Cis quadridens Mellié & 3 \\
\hline ?Symplecis sp. & 1 & Cis dentatus Mellié & 8 \\
\hline Orthocentrus sp. & 2 & Ennearthon cornutum (Gyllenhal) & 3 \\
\hline TOTAL & 93 & Ennearthon laricinum (Mellié) & 1 \\
\hline Coleoptera & & Hallomenus axillaris (Illiger) & 1 \\
\hline Ptiliidae & & Hallomenus sp. (larvae) & 1556 \\
\hline Acrotrichis sp. & 1 & Scolytidae & \\
\hline Leiodidae & & Dryocoetes autographus (Ratzeburg) & 2 \\
\hline Agathidium pisanum Brisout de Barneville & 4 & TOTAL & 1913 \\
\hline
\end{tabular}


Appendix 2. Taxa reared from Fomitopsis rosea.

\begin{tabular}{|c|c|c|c|}
\hline Species & Individuals & Species & Individuals \\
\hline Lepidoptera & & Coleoptera & \\
\hline Tineidae & & Ptiliidae & \\
\hline Agnathosia mendicella (Denis \& Schiffermüller) & 210 & Acrotrichis intermedia (Gillmeister) & 2 \\
\hline Montescardia tessulatella (Lienig \& Zeller) & 28 & Leiodidae & \\
\hline Oecophoridae & & Agathidium seminulum (Linnaeus) & 1 \\
\hline Schiffermuelleria stipella (Linnaeus) & 1 & Scydmaenidae & \\
\hline TOTAL & 239 & $\begin{array}{l}\text { Stenichnus collaris (Müller \& Kunze) } \\
\text { Stenichnus bicolor (Denny) }\end{array}$ & $\begin{array}{l}1 \\
1\end{array}$ \\
\hline Diptera & & Staphylinidae & \\
\hline Tachinidae & & Gabrius expectatus Smetana & 8 \\
\hline Elfia cingulata (Robineau-Desvoidy) & 115 & Hapalaraea linearis (Zetterstedt) & 4 \\
\hline Sciaridae & & Oxypoda skalitzkyi Bernhauer & 1 \\
\hline Trichosia (Baeosciara) sinuata & 34 & Oxypoda umbrata (Gyllenhal) & 2 \\
\hline Scatopsciara sp. & 3 & Ischnoglossa elegantula (Mannerheim) & 2 \\
\hline Corynoptera boletiphaga (Lengersdorf) & 1 & Atheta (Sg. Microdota) subtilis (Scriba) & 5 \\
\hline Leptosciarella sp. & 1 & Atheta (Sg. Xenota) myrmecobia (Kraatz) & 2 \\
\hline Indet & 5 & Atheta (Sg. Lypoglossa) lateralis (Mannerheim) & 1 \\
\hline TOTAL & 159 & Atheta pilicornis (Thomson) & 4 \\
\hline & & Bolitochara mulsanti Sharp & 1 \\
\hline Hymenoptera & & Leptusa pulchella (Mannerheim) & 1 \\
\hline Ichneumonidae & & Eucinetidae & \\
\hline Oxytorinae (Orthocentrinae) & & Eucilodes caucasicus (Reitter) & 3 \\
\hline Picrostigeus sp. & 1 & Elateridae & \\
\hline Stenomacrus curvulus (Thomson) & 16 & Harminius undulatus (Degeer) (larvae) & 1 \\
\hline Stenomacrus affinitor Aubert & 1 & Nitidulidae & \\
\hline Banchinae & & Epuraea marseuli Reitter & 2 \\
\hline Lissonota sp. & 4 & Cryptophagidae & \\
\hline Lissonota ?rusticator (Thunberg) & 2 & Cryptophagus acutangulus Gyllenhal & 2 \\
\hline Cryptinae & & Caenoscelis ferruginea (Sahlberg) & 2 \\
\hline Gelis sp. & 1 & Atomaria pulchra Erichson & 1 \\
\hline Braconidae & & Cerylonidae & \\
\hline Microgastrinae & & Cerylon histeroides (Fabricius) & 1 \\
\hline Choeras parasitellae (Bouché) & 2 & Corylophidae & \\
\hline Agathidinae & & Orthoperus atomus (Gyllenhal) & 1 \\
\hline Bassus calculator (Fabricius) & 1 & Latridiidae & \\
\hline Meteorinae & & Latridius consimilis Mannerheim & 1 \\
\hline ?Meteorus sp. & 1 & Latridius minutus (Linnaeus) & 2 \\
\hline Megaspilidae & & Corticaria interstitialis Mannerheim & 3 \\
\hline Megaspilinae & & Corticaria rubripes Mannerheim & 1 \\
\hline Conostigmus sp. & 1 & Corticaria polypori J.Sahlberg & 1 \\
\hline Diapriidae & & Corticaria longicollis (Zetterstedt) & 1 \\
\hline Betylinae & & Corticaria crenicollis Mannerheim & 2 \\
\hline Pantolytini & 1 & Corticaria ferruginea Marsham & 1 \\
\hline TOTAL & 31 & Cisidae & \\
\hline & & Cis glabratus Mellié & 13 \\
\hline & & Cis dentatus Mellié & 29 \\
\hline & & Ennearthon laricinum (Mellié) & 2 \\
\hline & & Scolytidae & \\
\hline & & Crypturgus hispidulus Thomson & 2 \\
\hline & & Dryocoetes autographus (Ratzeburg) & 2 \\
\hline & & TOTAL & 109 \\
\hline
\end{tabular}

